\title{
Comparison between irrigation and conventional treatment for empyema and pneumonectomy space infection
}

\author{
F L ROSENFELDT, D McGIBNEY, M V BRAIMBRIDGE, AND D A WATSON
}

From Killingbeck Hospital, Leeds, and The Department of Cardiothoracic Surgery, St Thomas' Hospital, London

ABSTRACT A new method of treating pleural empyema or pneumonectomy space infection by irrigation was evaluated in 11 patients. The infected cavities were filled with an antibiotic or antiseptic $>$ solution for three hours, and allowed to drain for one hour. This cycle was repeated every four hours‥ for seven to 10 days. When cultures of the infected cavity became sterile the irrigation tube was removed $\vec{\bullet}$ and the wound sealed. Using this method, infection was eradicated after an average of 11 days in five ${ }_{-}^{\infty}$ of six patients with pleural empyema and in all five patients treated for an infected pneumonectomy space, including one with a bronchopleural fistula. The results of treating 58 similar cases of intrapleural sepsis over a 10-year period by the standard methods of aspiration, open drainage, decortication, or thoracoplasty were compared with the results of irrigation. In general, cyclical irrigation resulted in a shorter hospital stay and a shorter period of wound drainage than other methods.

The goals of treatment for empyema are control of infection and obliteration of the cavity. The standard treatment of empyema is rib resection and open drainage via a wide bore basal tube. Methods of closed drainage are sometimes used but these have a high failure rate from inability to remove thick infected material through an intercostal tube or aspirating needle.

To overcome the problems associated with closed drainage, a regimen of irrigation has been developed in which a large volume of antibiotic or antiseptic solution is used to clean and sterilise the empyema cavity and the infected pneumonectomy space. In this report we compare the results of irrigation for empyema and pneumonectomy space infection with the results of conventional methods of treatment.

\section{Methods}

Over a three-year period, 11 patients were treated by irrigation at the Leeds General Infirmary, Killingbeck Hospital, and St Thomas' Hospital. Six patients had a pleural empyema and five an infected pneumonectomy space. The regimens used were as follows.

Address for reprint requests: FL Rosenfeldt, Baker Medical Resedrch Institute, Commercial Road, Prahran, 3181 Victoria, Australia.
REGIMEN FOR IRRIGATION OF A PLEURAL EMPYEMA

A double lumen tube was used for irrigation (fig 1). The irrigation fluid was introduced via the small lumen, and the larger outer tube with multiple sideo holes provided drainage. Initially this system was improvised by introducing an intravenous catheterơ into the lumen of an intercostal tube via a Y-piece. The double lumen tube is now available commerciallyô in two sizes: $9 \mathrm{~mm}$ and $12 \mathrm{~mm}$ outside diameter (Portex Ltd, Hythe, Kent).

Under local anaesthesia the $9 \mathrm{~mm}$ tube was inserted into the empyema cavity through the most dependent intercostal space using a trocar and cannula. The small lumen was connected to the irrigation drip and the drainage lumen to an underwater seal bottle 0 The irrigation fluid was normal saline containing either the antiseptic noxythiolin (Noxyflex) $1 \%$ or broad spectrum antibiotic combination to which theo infecting organism was sensitive, usually $2 \mathrm{~g}$ methicillin and $160 \mathrm{mg}$ of gentamicin in one litre. A seven $-?$ day systemic course of the appropriate antibiotic wast begun. Immediately after insertion of the tube, the cavity was washed out rapidly several times to clearn most of the pus and then cyclical irrigation begun as follows: the irrigation fluid was run in to fill the cavity; the fluid was retained in the chest for three hours and then allowed to drain for one hour witho suction. This cycle was repeated four hourly. 


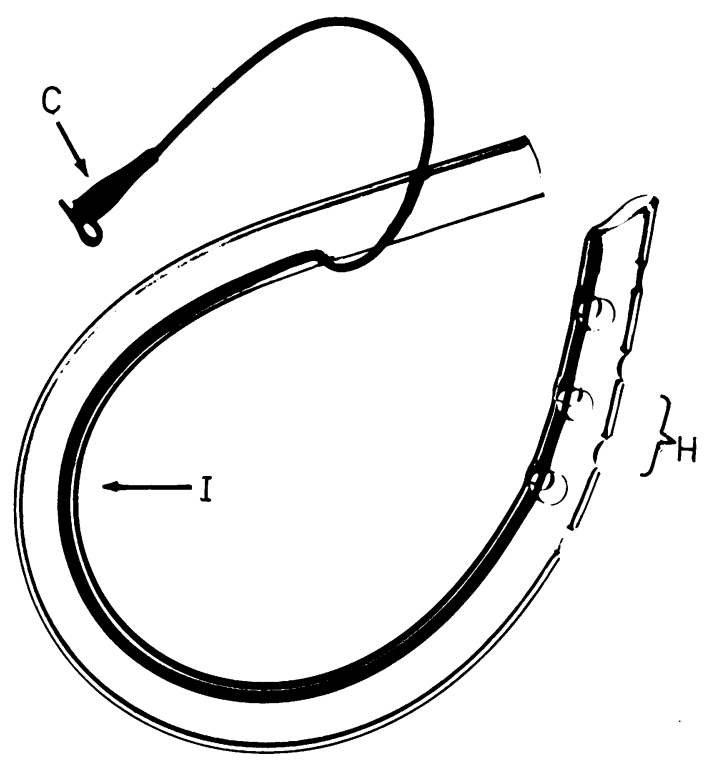

Fig 1 Double lumen irrigation tube. $C=$ connection to irrigation lumen, $I=$ irrigation lumen, $H=$ multiple side holes in drainage lumen.

A build-up of pressure in the pleural space may cause troublesome leakage of irrigation fluid around the drainage tube. To prevent this two precautions were taken. First, while the fluid was running in, the patient lay on his unaffected side with the drainage tube uppermost. This allowed fluid to displace air upwards and out of the chest. Second, to retain fluid in the chest, instead of clamping the basal drain, the connecting tubing running to the underwater seal was simply raised to the level of the suprasternal notch (fig 2). The head of water in the tubing was sufficient to retain fluid in the chest and also acted as a pressurerelease valve during coughing or straining. Irrigation was performed during waking hours and irrigation fluid left in the chest overnight.

When the effluent was clear, usually after seven to 10 days, the irrigation fluid was changed to normal saline and samples of the effluent sent for culture. If the cultures were sterile, $100 \mathrm{ml}$ of concentrated irrigation fluid was left in the cavity, the tube removed, and the wound sealed. The concentrated irrigation fluid contained the dose of antibiotic usually added to one litre of saline or was a saturated solution of noxythiolin. On alternate days the pleural space was aspirated and antiseptic or antibiotics instilled. If the samples were sterile on three separate occasions the patient was allowed home. At one week and one month after discharge from hospital, pleural fluid was again sampled if possible, and concentrated irrigation fluid instilled.

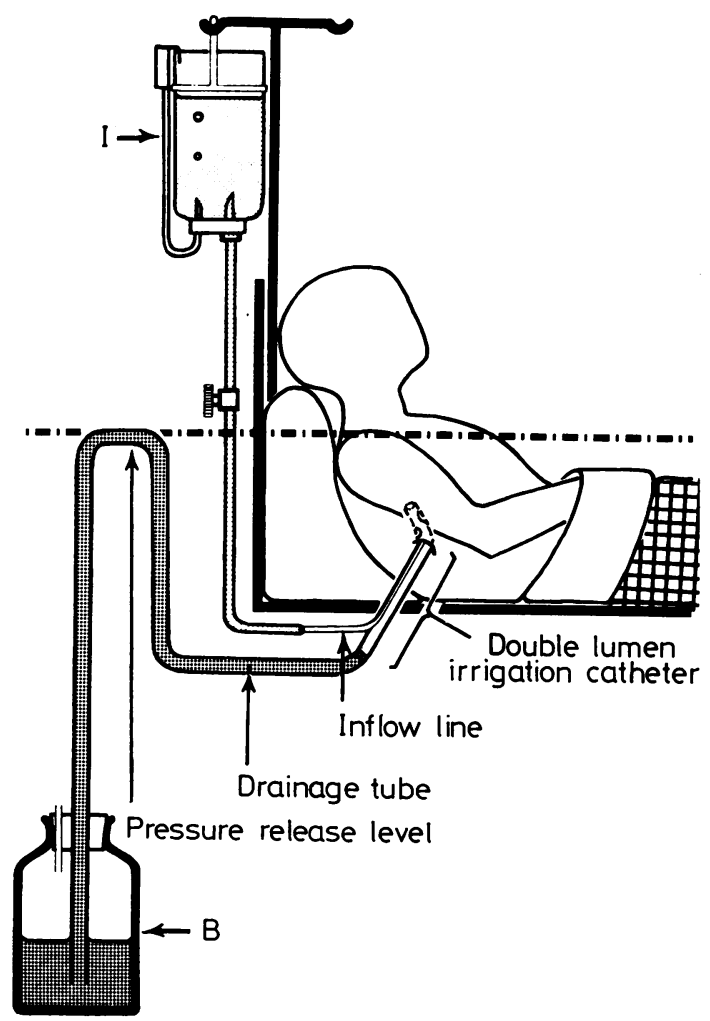

Fig 2 Pressure release system for pleural irrigation. The drainage tubing is raised to the level of the suprasternal notch (dotted line). The liquid column in the tubing retains irrigation fluid in the chest yet prevents leakage around the irrigation catheter by allowing overspill during coughing or straining. $I=$ bottle of irrigation fluid, $B=$ underwater seal bottle.

\section{REGIMEN FOR IRRIGATION FOR AN INFECTED}

PNEUMONECTOMY SPACE

Under general anaesthesia a bronchoscopy was carried out and the bronchial stump inspected for a fistula. A large trocar and cannula was then inserted through the most dependent intercostal space. Using copious irrigation and a long sucker, as much as possible of the infected material was removed.

Provided a bronchopleural fistula was not present the following procedure was adopted. The $12 \mathrm{~mm}$ double lumen tube was inserted into the base of the cavity. The small lumen was connected to the irrigation drip and the drainage lumen to an underwater seal bottle. The cavity was irrigated with the same fluids used for pleural empyema. Enough fluid was run in to fill the space almost completely. The fluid was retained in the chest for three hours, and then allowed to drain out for one hour without suction. 
Leakage of fluid around the drainage tube was occasionally troublesome because of the rigidity of the walls of the pneumonectomy space. This could be largely prevented by the methods previously described.

As with the empyema regimen, a seven-day course of the appropriate antibiotic was given systemically during the course of irrigation. The subsequent management was as already described for empyema.

A large bronchopleural fistula was a contraindication to this technique. However in the presence of a small bronchopleural fistula irrigation could still be used, with the following modifications. The irrigation lumen of the double lumen tube was not used. Through the second or third anterior intercostal space an 18-gauge intravenous catheter was introduced into the apical part of the cavity and connected to the irrigation drip. Irrigating fluid was dripped in continuously via the apical catheter and the basal tube allowed to drain continuously. The patient lay on his affected side with the fistula uppermost so that the fluid bathed the pneumonectomy space without entering the trachea. If there was any suspicion of irrigation fluid entering the bronchial tree, $2 \mathrm{ml}$ of fluoroscein was added to the ingoing fluid and the patient's sputum observed for greenish coloration. When the fistula had closed, the four-hourly highvolume regimen was used.

\section{COMPARISON WITH ALTERNATIVE}

\section{METHODS OF TREATMENT}

The case notes were reviewed of patients with nontuberculous pleural empyema or pneumonectomy space infection who were admitted between 1966 and 1976 to Killingbeck Hospital or the Leeds General Infirmary.
Particular note was made of the duration of pleural drainage and hospital stay after the infection was diagnosed. The treatments used for empyemas were intermittent needle aspiration with instillation of antibiotics, rib resection and drainage, or decortication. Pneumonectomy space infections were treated by thoracoplasty or permanent thoracostomy drainage.

\section{Results}

\section{EMPYEMA}

The results of treatment of empyema by irrigation are shown in table 1 . There were four males and two females ranging in age from 13 to 69 years. The estimated duration of the empyema before treatment was three and a half weeks (range one to five weeks). In all cases the diagnosis was made by the aspiration of frank pus from the empyema cavity. Four were irrigated with an antibiotic and two with an antiseptic solution. In five of the six patients the treatment was successful. The one failure was a caseof staphylococcal pyopneumothorax with a bronchopleural fistula. The lung could not be kept expanded nor could the pleural space be sterilised. The patient subsequently required decortication.

Table 2 gives a comparison of the results of treatment of empyema by irrigation with the results of other forms of treatment. Intermittent needle aspiration and instillation of antibiotic was associated with a high failure rate: in five patients the infection was cleared but four out of nine required decortication. In 14 patients treated by rib resection and tube drainage there was one perioperative death. An average of 11 weeks was required for the sinus to close.

Table 1 Irrigation of pleural empyema

\begin{tabular}{|c|c|c|c|c|c|c|c|}
\hline Case & $\begin{array}{l}\text { Age } \\
(v r)\end{array}$ & $\operatorname{Sex}$ & Organism & Irrigation fluid & $\begin{array}{l}\text { Duration } \\
\text { of } \\
\text { drainage } \\
\text { (days) }\end{array}$ & $\begin{array}{l}\text { Duration of } \\
\text { hospital } \\
\text { stay } \\
\text { (days) }\end{array}$ & Result \\
\hline 1 & 13 & $\mathbf{M}$ & $\begin{array}{l}\text { Non-haemolytic } \\
\text { streptococcus }\end{array}$ & Penicillin and gentamicin & 5 & 13 & $\begin{array}{l}\text { Rapid sterilisation, and } \\
\text { clinical improvement }\end{array}$ \\
\hline 2 & 30 & $\mathbf{M}$ & No growth & Methicillin and gentamicin & 9 & 17 & Rapid clinical improvement \\
\hline 3 & 63 & $\mathbf{M}$ & No growth & Methicillin and gentamicin & 10 & 31 & Rapid clinical improvement \\
\hline 4 & 57 & $\mathbf{M}$ & $\begin{array}{l}\text { Staphylococcus aureus } \\
\text { later Coliforms Klebsiella } \\
\text { Candida }\end{array}$ & $\begin{array}{l}\text { Methicillin, gentamicin, and } \\
\text { nystatin }\end{array}$ & 42 & $\begin{array}{l}85 \text { (including } \\
\text { decortication) }\end{array}$ & $\begin{array}{l}\text { Persistent infection. Lung } \\
\text { would not expand because of } \\
\text { large bronchopleural fistula. } \\
\text { Needed decortication }\end{array}$ \\
\hline 5 & 69 & $\mathbf{F}$ & Staphylococcus aureus & Noxythiolin $1 \%$ & 10 & 29 & $\begin{array}{l}\text { Rapid sterilisation and clinical } \\
\text { improvement; some residual } \\
\text { pleural thickening (three } \\
\text { previous empyemas in same } \\
\text { site) }\end{array}$ \\
\hline 6 & 69 & $\mathbf{F}$ & Streptococcus Milleri & Noxythiolin $1 \%$ & 21 & 27 & $\begin{array}{l}\text { Required two eight-day } \\
\text { courses of irrigation for } \\
\text { sterilisation. Good clinical } \\
\text { result }\end{array}$ \\
\hline
\end{tabular}


Table 2 Pleural empyema: comparison of results of irrigation and other treatments

\begin{tabular}{|c|c|c|c|c|c|c|}
\hline Treatment & $\begin{array}{l}\text { Number of } \\
\text { patients }\end{array}$ & $\begin{array}{l}\text { Average age }(y r) \\
\text { (range) }\end{array}$ & Sex & $\begin{array}{l}\text { Average duration } \\
\text { drainage } \\
\text { (weeks) }\end{array}$ & $\begin{array}{l}\text { Average duration } \\
\text { of hospital stay } \\
\text { (weeks) }\end{array}$ & Result \\
\hline Irrigation & 6 & $\begin{array}{l}50 \\
(13-69)\end{array}$ & $\begin{array}{l}4 \mathrm{M} \\
2 \mathrm{~F}\end{array}$ & 2 & $\begin{array}{l}5 \\
(2-12)\end{array}$ & Five resolved, one failed* \\
\hline $\begin{array}{l}\text { Needle aspiration and } \\
\text { instillation of antibiotics }\end{array}$ & 9 & $\begin{array}{l}54 \\
(19-72)\end{array}$ & $\begin{array}{l}5 \mathrm{M} \\
4 \mathrm{~F}\end{array}$ & 0 & $\begin{array}{l}7 \\
(3-17)\end{array}$ & $\begin{array}{l}\text { Five resolved, four failed,* } \\
\text { no deaths }\end{array}$ \\
\hline $\begin{array}{l}\text { Rib resection and tube } \\
\text { drainage }\end{array}$ & 14 & $\begin{array}{l}44 \\
(0 \cdot 5-66)\end{array}$ & $\begin{array}{l}7 \mathrm{M} \\
7 \mathrm{~F}\end{array}$ & $\begin{array}{l}11 \\
(3-33)\end{array}$ & $\begin{array}{l}3 \cdot 5 \\
(2-7)\end{array}$ & $\begin{array}{l}10 \text { resolved, one still } \\
\text { draining after one year, } \\
\text { three deaths (one perioper- } \\
\text { ative, two unrelated) }\end{array}$ \\
\hline Decortication & 18 & $\begin{array}{l}48 \\
(18-70)\end{array}$ & $\begin{array}{c}14 \mathrm{M} \\
4 \mathrm{~F}\end{array}$ & $\begin{array}{l}11 \\
(1-46)\end{array}$ & $\begin{array}{l}7 \cdot 5 \\
(2 \cdot .24)\end{array}$ & $\begin{array}{l}14 \text { resolved, three peri- } \\
\text { operative deaths, one death } \\
\text { from malignancy }\end{array}$ \\
\hline
\end{tabular}

*Proceeded to decortication.

In 18 patients treated by decortication there were three perioperative deaths and one unrelated death. In the remainder, treatment was successful. The average duration of wound drainage for the decortication group was 11 weeks. This surprisingly high average was caused partly by five patients who had discharging sinuses for between three and 10 months.

The average duration of drainage for the irrigation group was two weeks compared with 11 weeks for rib resection or decortication. The average hospital stay for the entire irrigation group (six patients) was five weeks but only three weeks in the five successful cases. This compares with three and a half weeks for rib resection, seven weeks for needle aspiration, and seven and a half weeks for decortication.

\section{PNEUMONECTOMY SPACE INFECTION}

Table 3 shows the results of irrigation for pneumonectomy space infection in five patients. Four were irrigated with antibiotics and one with noxythiolin.
One patient (case 11) had a bronchopleural fistula which was small and closed spontaneously once the infection was controlled. Another (case 10) died in hospital from a subphrenic haemorrhage after diaphragmatic trauma during the pleural aspiration at the end of the course of irrigation. The pleural space was sterile at the time of death.

Table 4 contains a comparison of the results of treatment of pneumonectomy space infection by irrigation with the results of other forms of treatment. In the thoracoplasty group, more than half the patients had bronchopleural fistulae; the results were not encouraging. Four of the 11 died at operation or in the perioperative period, and the survivors had a discharging sinus for nearly a year. In the permanent drainage group no attempt was made to sterilise the infected space. However one cure was recorded. Of the other five, one was still draining at the time of the survey; the others were draining at the time of death.

Table 3 Irrigation treatment of pneumonectomy space infection

\begin{tabular}{|c|c|c|c|c|c|c|c|c|c|}
\hline Case & $\begin{array}{l}\text { Age } \\
(y r)\end{array}$ & Sex & $\begin{array}{l}\text { Broncho- } \\
\text { pleural } \\
\text { fistula }\end{array}$ & Organism & $\begin{array}{l}\text { Time } \\
\text { between } \\
\text { operation } \\
\text { and } \\
\text { empyema }\end{array}$ & Irrigation & $\begin{array}{l}\text { Duration } \\
\text { of } \\
\text { drainage } \\
\text { (days) }\end{array}$ & $\begin{array}{l}\text { Duration } \\
\text { of } \\
\text { hospital } \\
\text { stay } \\
\text { (days) }\end{array}$ & Result \\
\hline 7 & 49 & $\mathbf{M}$ & No & $\begin{array}{l}\text { Klebsiella aerogenes } \\
\text { Staph aureus }\end{array}$ & $7 \mathrm{wk}$ & $\begin{array}{l}\text { Ampicillin and } \\
\text { gentamicin }\end{array}$ & 12 & 26 & $\begin{array}{l}\text { Well with no recurrence at } \\
\text { two years }\end{array}$ \\
\hline 8 & 59 & $\mathbf{M}$ & No & Staph aureus & $6 \mathrm{wk}$ & $\begin{array}{l}\text { Methicillin and } \\
\text { gentamicin }\end{array}$ & 9 & 18 & $\begin{array}{l}\text { No recurrence of infection. } \\
\text { Died after } 18 \text { months from } \\
\text { recurrent carcinoma }\end{array}$ \\
\hline 9 & 60 & $\mathbf{M}$ & No & Staph aureus & $12 \mathrm{~d}$ & $\begin{array}{l}\text { Methicillin and } \\
\text { gentamicin }\end{array}$ & 9 & 44 & $\begin{array}{l}\text { No recurrence of infection. } \\
\text { Died after two months from } \\
\text { metastatic carcinoma }\end{array}$ \\
\hline 10 & 45 & $\mathbf{M}$ & No & $\begin{array}{l}\text { Haemophilus } \\
\text { influenzae }\end{array}$ & $14 d$ & $\begin{array}{l}\text { Methicillin and } \\
\text { gentamicin }\end{array}$ & 11 & $\begin{array}{l}\text { (died after } \\
11 \text { ) }\end{array}$ & $\begin{array}{l}\text { Cultures sterile, tube } \\
\text { removed. Died from } \\
\text { haemorrhage caused by } \\
\text { laceration of phrenic } \\
\text { artery during pleural } \\
\text { aspiration }\end{array}$ \\
\hline 11 & 69 & $\mathbf{M}$ & Yes & $\begin{array}{l}\text { Streptococcus Milleri } \\
\text { Candida albicans }\end{array}$ & $3.5 \mathrm{yr}$ & Noxythiolin & 10 & 38 & $\begin{array}{l}\text { No recurrence of infection } \\
\text { after one year }\end{array}$ \\
\hline
\end{tabular}


Table 4 Pneumonectomy space infection: comparison of results of irrigation and other treatments

\begin{tabular}{|c|c|c|c|c|c|c|c|}
\hline Treatment & $\begin{array}{l}\text { Number of } \\
\text { patients }\end{array}$ & $\begin{array}{l}\text { Number with } \\
\text { bronchial } \\
\text { fistulae }\end{array}$ & $\begin{array}{l}\text { Age }(y r) \\
\text { (range) }\end{array}$ & $\operatorname{Sex}$ & $\begin{array}{l}\text { Duration of } \\
\text { drainage* } \\
\text { (weeks) }\end{array}$ & $\begin{array}{l}\text { Duration of } \\
\text { hospital stay* } \\
\text { (weeks) }\end{array}$ & Result \\
\hline Irrigation & 5 & 1 & $\begin{array}{l}56 \\
(45-69)\end{array}$ & $5 \mathbf{M}$ & $1 \cdot 5$ & $\begin{array}{l}4 \cdot 5 \\
(1 \cdot 5-6)\end{array}$ & $\begin{array}{l}\text { Four resolved, one early } \\
\text { death }\end{array}$ \\
\hline Thoracoplasty & 11 & 6 & $\begin{array}{l}60 \\
(36-76)\end{array}$ & $\begin{aligned} 10 \mathrm{M} \\
1 \mathrm{~F}\end{aligned}$ & $\begin{array}{l}46 \\
(14-100)\end{array}$ & $\begin{array}{l}8 \\
(5-16)\end{array}$ & $\begin{array}{l}\text { Seven resolved, four early } \\
\text { deaths (operative and } \\
\text { perioperative) }\end{array}$ \\
\hline Permanent drainage & 6 & 1 & $\begin{array}{l}64 \\
(54-72)\end{array}$ & $6 \mathrm{M}$ & - & 11 & $\begin{array}{l}\text { One resolved, four died } \\
\text { after an average of } 45 \text { weeks } \\
\text { still draining }\end{array}$ \\
\hline
\end{tabular}

*In survivors only.

\section{Discussion}

Empyema is a condition for which a wide range of treatments is used. The options in any particular case are generally determined by the nature of the empyema. At one end of the pathological spectrum is the acute empyema which complicates pneumonia and which is diagnosed early. Here the pus is thin, the walls of the cavity fibrinous, and aspiration through a needle is possible. At the other end is the chronic empyema which is diagnosed late. Here the pus is viscous enough to block any but the largest drainage tube, and the walls of the cavity have become thick and fibrous. The majority of empyemas fall between these extremes and present the physician or surgeon with a choice of treatment by intermittent drainage or continuous drainage, rib resection, or thoracotomy.

In a series of 500 empyemas reported by Le Roux, ${ }^{1}$ 82 were initially managed by closed drainage; of these only six were successfully managed by needle aspiration alone. In our series, nine cases were treated by needle aspiration and instillation of antibiotics; however, four subsequently required decortication.

Closed drainage without irrigation is used frequently as an emergency measure to reduce toxaemia in a seriously ill patient. However, it has limitations. It should not be used when thick pus is present because drainage will be impaired by fibrin masses. Without rib resection, it is difficult and may indeed be dangerous to attempt to place the tube at a completely dependent site. As a blind manoeuvre, such an attempt may result in perforation of the diaphragm. ${ }^{2}$

Cyclical irrigation extends the scope and efficiency of closed drainage in three ways. It keeps the tube patent even when thick pus is present, it flushes the base of the cavity even if the tube is not completely basal, and it delivers a high concentration of antibacterial drug to all areas of the empyema. Since it is not necessary to place a wide bore basal drain by means of a rib resection, the irrigation catheter can be inserted under local anaesthesia in the ward. Once the irrigation system has been set up it can be run by the nursing staff. The results of this series suggest that in suitable cases, irrigation techniques can shorten the hospital stay and the duration of drainage.

In one of our cases (case 2) intercostal tube drainage and irrigation was carried out as a preliminary measure to reduce toxaemia before decortication. The patient's clinical response was so dramatic and his radiological improvement so good that decortication was considered unnecessary. Case 4 illustrated the mistake of persisting with irrigation in an unsuitable case. Successful cases normally had sterile cultures within 10 days. If irrigation has not succeeded in sterilising the pleural space within 10-14 days it should usually be abandoned and decortication performed.

Decortication is the treatment of choice for the chronic empyema with a thick peel over a large area of the lung. However, irrigation may be useful in sterilising a large chronic empyema in an old or debilitated patient who would not readily tolerate an extensive decortication. This situation is illustrated by patient 5 who had three previous empyemas at the same lung base treated by aspiration over a period of one year. Her empyema was easily sterilised by irrigation. Early in the recovery period her chest expansion was reduced but this improved somewhat over the succeeding months.

In the management of infection after pneumonectomy, sterilisation of the space is greatly preferable to thoracoplasty. Total thoracoplasty after pneumonectomy is a daunting surgical procedure. It is often not feasible because of the patient's age and debility, and in many cases, not indicated because of the likelihood of early recurrence of the tumour. In our series, thoracoplasty was associated with a $36 \%$ mortality rate and an average hospital stay of two months. In addition it was 11 months on average before all drainage ceased from the operative site.

Clagett and associates ${ }^{3} 4$ described a two-stage method for sterilising the infected penumonectomy space. First a large window is made in the chest wall through which the infected space is bathed with antiseptic. Two months later the window is closed 
after filling the space with neomycin solution. This method was successful in 16 out of 18 patients. Conklin ${ }^{5}$ reported a modification of Clagett's method in which thoracotomy, cleansing, filling with neomycin, and definitive closure were carried out as a single operative procedure in two patients. Clagett's method entails a prolonged course of irrigation before the chest can be closed and has the danger of neomycin toxicity. ${ }^{6}$ Sturridge $^{7}$ has described a regimen comprising a period of temporary drainage via an intercostal tube followed by instillation of antibiotics via a small indwelling pleural catheter. Goldstraw recently reported 29 patients with postpneumonectomy empyema treated by fenestration (thoracostomy). ${ }^{8}$ Seventeen of these $(59 \%)$ successfully underwent closure after an average of 40 days of lavage with cetrimide in hospital. A further two patients required two successive fenestrations and delayed closure procedures before sterility was achieved.

The method we have described of sterilising the pneumonectomy space by irrigation results in a short hospital stay and little discomfort to the patient. One patient in our series had a bronchopleural fistula which healed during the period of irrigation. Kärkölä et al ${ }^{9}$ reported the successful use of a regimen of irrigation similar to our own in seven patients with post-pneumonectomy empyema. Four of the seven had bronchopleural fistulae which healed during a four-week period of irrigation.

The use of noxythiolin as an irrigation fluid has advantages over antibiotic irrigation. First, noxythiolin has a powerful anti-bacterial effect and a broad spectrum of activity. Bacterial resistance is very rare and when it occurs it is not absolute. ${ }^{10}$ Second, noxythiolin is fungicidal. ${ }^{11}$ Fungi were cultured from two of our patients treated by irrigation and from at least one patient treated by needle aspiration. Fungal superinfection in the pleural space is likely to arise when broad spectrum antibiotics are used for long periods of time in the presence of a cavity with a fistula. Noxythiolin may be useful in eradicating established fungal infection and in preventing reinfection during irrigation. One disadvantage of noxythiolin is the occurrence of systemic absorption during intrapleural therapy. ${ }^{12}$ Although this may cause temporary nausea and vomiting, these sideeffects can be lessened by reducing the volume or frequency of irrigation.
Powerful antibiotics such as neomycin and strong antiseptics such as povidone iodine are probably unsuitable for use with this regimen of high volume irrigation because of the risk of excessive absorption and the known incidence of systemic toxicity with these compounds. ${ }^{613}$ Cetrimide has a weaker activity against gram-negative bacteria and fungi than noxythiolin.

We conclude that this technique of cyclical irrigation with antibacterial solutions is an effective and convenient method of treating pleural infection that produces minimum patient discomfort and shortens the duration of hospital stay.

\section{References}

1 Le Roux BT. Empyema thoracis. Br J Surg 1965; 52:89-99.

2 Samson PC. Empyema thoracis: essentials of presentday management. Ann Thorac Surg 1971; 11:210-21.

3 Clagett OT, Geraci JE. A procedure for the management of postpneumonectomy empyema. $J$ Thorac Cardiovasc Surg 1963; 45: 141-5.

4 Stafford EG, Clagett OT. Postpneumonectomy empyema: neomycin instillation and definitive closure. J Thorac Cardiovasc Surg 1972; 63:771-5.

5 Conklin WS. Post-pneumonectomy empyema : singlestage operative treatment. J Thorac Cardiovasc Surg 1968; 55:634-7.

6 Meakins JL, Allard J. Neomycin absorption following Clagett procedure for postpneumonectomy empyema. Ann Thorac Surg 1980; 29: 32-5.

7 Sturridge MF. Postpneumonectomy empyema. In Jackson JW, ed. Cardiothoracic surgery. Third edition London. Butterworths, 1978: 347-8.

8 Goldstraw P. Treatment of postpneumonectomy empyema: the case for fenestration. Thorax 1979; 34:740-5.

9 Kärkölä P, Kairaluoma MI, Larmi TKI. Postpneumonectomy empyema in pulmonary carcinoma patients: treatment with antibiotic irrigation and closed-chest drainage. J Thorac Cardiovasc Surg 1976; 72:319-22.

10 Chattopadhyay B. Noxythiolin-resistant organisms in a district general hospital. Br MedJ 1977;2:1121-2.

11 Martindale. Extra Pharmacopoea. Twenty-seventh edition. London: Pharmaceutical Press, 1977: 526-7.

12 Rosenfeldt FL, Glover JR, Marossy D. Systemic absorption of noxythiolin from the pleural cavity in man and in the rabbit. Thorax 1981;36:278-81.

13 Pietsch J, Meakins JL. Complications of povidoneiodine absorption in topically treated burn patients. Lancet 1976; $1: 280-2$. 